\title{
New Geographical Record of Three Cumacean Species Eudorella nana, Leucon affinis, Leucon siphonatus and One Rare Amphipod Presence Confirmation, Stenothoe bosphorana, in Adriatic Sea, Italy
}

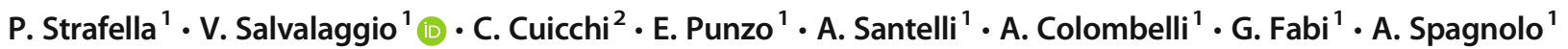

Received: 27 October 2020 / Revised: 8 February 2021 / Accepted: 25 February 2021 / Published online: 5 June 2021

(C) The Author(s) 2021

\begin{abstract}
Three cumacean species, Eudorella nana Sars, 1879, Leucon affinis Fage, 1951, Leucon siphonatus Calman, 1905, were recorded for the first time and one rare amphipod presence, Stenothoe bosphorana Sowinsky, 1898, was confirmed in the Adriatic basin.
\end{abstract}

Keywords First records $\cdot$ Eudorella nana $\cdot$ Leucon affinis $\cdot$ Leucon siphonatus $\cdot$ Stenothoe bosphorana $\cdot$ Adriatic Sea

\section{Introduction}

The importance of the taxonomist work in biological and ecological research as well as in biodiversity management is well known, even though most of the time it is underestimated. Misidentification of specimens may have some consequences on the accuracy of ecological works and furthermore in fields like medicine, pharmacology, agriculture, conservation biology, ecosystem management and climatology (Dubois et al. 2013).

Some species may be also widely confused by "non-specialized" taxonomists with other similar but common species and this is a possible reason for their rareness.

Three cumaceans belonging to family Leuconidae Sars, 1878 are presented here as first record in the Adriatic Sea. Leuconidae is one of the earliest established cumacean families with no free telson, endopod of the uropod with two articles (rarely one) and which can occasionally have a functional eye (Watling 1991). Currently, the presence of Eudorella Norman, 1867 and Leucon Krøyer, 1846 genera in the Atlantic Ocean and in the Mediterranean basin (western Mediterranean, Ionian, Aegean and Levantine Seas) is documented by different authors (Lagardère, 1977; Elizalde et al.

V. Salvalaggio

vera.salvalaggio@cnr.it

1 CNR IRBIM - National Research Council - Institute of Marine Biological Resources and Biotechnologies, Ancona, AN, Italy

2 Cooperativa Mare Ricerca, Ancona, Italy
1993; Gerken and Watling 1999; Madurell and Cartes 2003; Cartes et al. 2007, 2011; Fanelli et al. 2009; MühlenhardtSiegel 2009; Marusso 2010; Frutos and Sorbe 2014, 2017; Corbera and Sorbe 2020). Within the Mediterranean Sea these genera are represented by 3 (Eudorella) and 10 (Leucon) species (Marusso 2010), while only few studies reported them in the Italian waters (Graeffe 1902; Casellato et al. 2007; Casellato and Stefanon 2008; Klepal and Kastner 1980; Ligas et al. 2009; Coll et al. 2010).

Family Stenothoidae Boeck, 1871 was initially described, together with Amphilochidae Boeck, 1871, as a subfamily of Leucothoidae Dana, 1852 (Boeck 1871; Bousfield 1982), due to the presence in these families of very close characters at pereopods, uropods and mouthparts levels. Subsequently, Sars (1892) classified both Stenothoidae and Amphilochidae at family level (Krapp-Schickel and Koenemann 2006).

Among the 46 genera included within Stenothoidae the most represented is Stenothoe Dana, 1852 with 60 valid species already described, closely followed by Metopa Boeck, 1871 with 54 species (WoRMS Editorial Board 2020).

In 2006, Krapp-Schickel proposed a classification of the genus Stenothoe based on the presence of carinate body, prehensile pereopods and a naked or spinose telson. In 2015 the same author re-described the entire genus dividing the 55 valid species attributed since then in two groups: the largest one comprehending those species more similar to $S$. valida and the smaller one including those species similar to S. monoculoides (Krapp-Schickel 2015, 2006).

The genus Stenothoe is widely distributed all over the world from boreal to temperate regions (Myers 1985; Bellan-Santini 2005; Hayward and Morley 2005; Krapp- 
Schickel 2006; Krapp-Schickel et al. 2015; Krapp-Schickel and Lo Brutto 2015), both as free-living and in association with sea anemones (Vader 1984; Vader and Krapp-Schickel 1996; Krapp-Schickel 2015).

Up to date, only 14 out of 60 amphipods belonging to the genus Stenothoe are known to be distributed within the Mediterranean Sea (Marin and Sinelnikov 2018) and within them only S. bosphorana Sowinsky, 1898 is still considered as an endemic species (Krapp-Schickel 2015). There was only one old record of this species along the coast of Zlarin Island, Croatia (Krapp-Schickel 1976) without any further information since then.

The contribution of this paper is to rise the knowledge on the macrozoobenthos biodiversity, adding four smalls, but not less important, crustacean species to the Adriatic Sea fauna.

It is well known the importance of the biodiversity, to the point that the first descriptor of the "Good Environmental Status (GES)" of the EU Marine Strategy Framework Directive (MSFD; Directive 2008/56/EC) is, quoting: "Biological diversity is maintained. The quality and occurrence of habitats and the distribution and abundance of species are in line with prevailing physiographic, geographic and climate conditions". In this contest, it is clear the role of taxonomists and the relevance of knowing the distribution of every single species in the biodiversity point of view; furthermore, to understand the spreading of some species (alien and/or invasive) due to climate changes and human activities is extremely crucial to have a clear picture of the native or already present species in a certain place.

\section{Materials and Methods}

Study Area The Adriatic Sea is an elongated basin in the northernmost part of the Mediterranean, between the Italian Peninsula and the Balkans countries, with the major axis in the NW-SE direction. The northern area is very shallow, gently sloping, with an average depth of about $35 \mathrm{~m}$, while the central part is on average $140 \mathrm{~m}$ depth, with 2 pits, the Pomo pit reaching $\approx 260 \mathrm{~m}$ and the South Adriatic pit reaching $\approx 1200 \mathrm{~m}$. The northern and central parts of the basin are affected by a great number of rivers along the Italian coast, with the Po River being the most relevant in terms of water inflow (Artegiani et al. 1997). River runoff and wind stress are the main drivers of the water circulation. West Adriatic Current (WAC) and East Adriatic Current (EAC), flowing along the coasts, are the main currents affecting the Adriatic circulation. There are three main cyclonic gyres, one in the northern part, one in the middle and one in the south (Artegiani et al. 1997).

In the southern Adriatic Sea, the cyclonic gyre is observed in all seasons and a relatively strong western coastal current and a weaker eastern current are observed during summer. A strong annual thermal variation affects the northern and central Adriatic Sea and it is more pronounced at the surface (e.g., $5-28{ }^{\circ} \mathrm{C}$ ) than close to the bottom (e.g., $12-17^{\circ} \mathrm{C}$ ). The water column from the coast to the $11-12 \mathrm{~km}$ offshore is characterized by low temperature $\left(5-6{ }^{\circ} \mathrm{C}\right)$ and salinity $(<37 \%$ o $)$ in winter, while the offshore waters are warmer $\left(10-12{ }^{\circ} \mathrm{C}\right)$ and thicker $(>38 \%$ ) . A vertical thermohaline front, parallel to the coast and extended throughout the water mass, divides the coastal waters from the open sea. In summer, instead, a horizontal stratification characterizes the water column, separating the warmer surface waters with lower salinity, from the deeper, colder and more saline ones (Artegiani et al. 1997).

The area is affected by a heavy marine traffic from cargo ships, supplier vessels for offshore activities (e.g., gas platforms), ferryboats, trawl-fishing vessels, cruise and recreational crafts (Coll et al. 2007; Pranovi et al. 2016). It is also characterized by intense mussel aquaculture along the Italian coast and by fish farming along the Croatian one (Ponti et al. 2007; Fabi et al. 2009).

Samples Collection and Analysis Macrozoobenthos samples were collected during different surveys, from 2012 to 2019, within a multi-annual monitoring program aimed to assess the environmental effects of offshore gas extraction platforms.

Sampling was performed at three different square areas (A, $\mathrm{B}, \mathrm{C}$ ) of the central Adriatic Sea, each having a surface area of $\approx 16 \mathrm{~km}^{2}$ (Fig. 1; Table 1).

Twenty-four sites where randomly chosen within each area and six samples were collected at each site using a Van-Veen grab (capacity $13.0 \mathrm{~L}$; surface $0.1 \mathrm{~m}^{2}$ ). The grab samples were sieved in situ through a $0.5 \mathrm{~mm}$ mesh, preserved in 5\% buffered formalin and later transferred to $70 \%$ ethanol. Macrozoobenthos was sorted and identified in the laboratory using a stereomicroscope Zeiss Stemi 2000C and a compound microscope Zeiss Axiolab 5 equipped with eyepiece reticles, stage micrometers and camera.

The specimens herein examined and descripted are the first of the total recorded (Table 2) during the whole surveys period. All the specimens were measured in size (Total Body Length, TL), dissected when necessary, examined under higher magnification and identified following the below-mentioned systematic keys and descriptions.

Bellan-Santini et al. (1993) and Krapp-Schickel (2015) for the amphipod and Băcescu (1951), Fage (1951), Jones (1976) and Shalla (2011) for the cumaceans were followed for the systematic keys and description.

For some individuals of each species, pictures of body parts were taken using Zeiss Axiocam ERC5s 5mpx. The handmade draws were obtained from the pictures, using XP-PEN Graphic Tablet Deco 02 Pen 8192 and Autodesk SketchBook software. 
Fig. 1 Geographical overview of the Adriatic Sea with the details of the surveyed areas

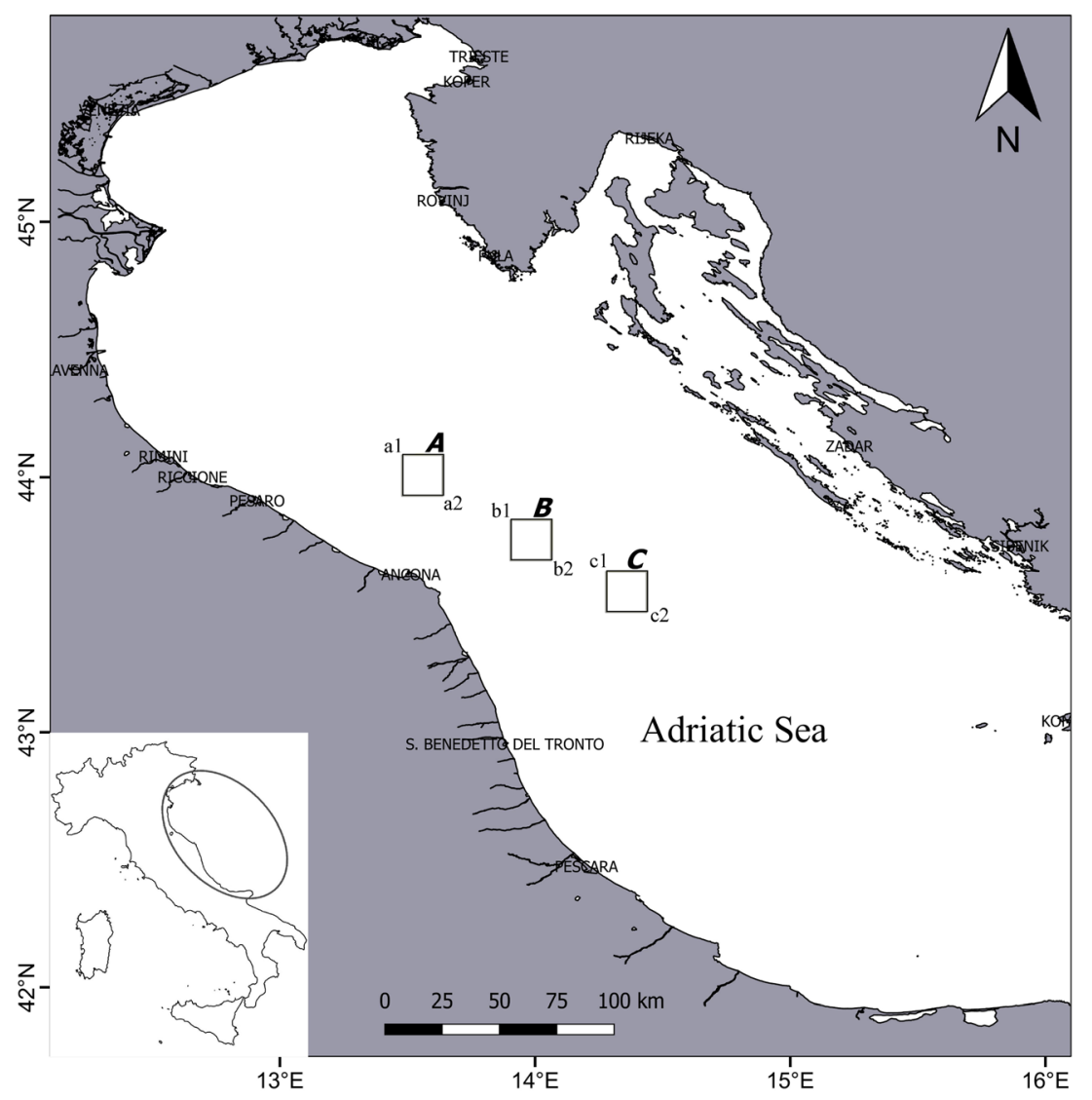

The nomenclature herein follows the World Register of Marine Species (WoRMS Editorial Board 2020). Voucher specimens are presently kept in the reference collection of CNR-IRBIM in Ancona, Italy.

\section{Results}

During the overall sampling period, 7 E. nana and 11 L. affinis were found in A and B areas, 274 L. siphonatus in A, B and C areas and $3 \mathrm{~S}$. bosphorana were only found in C area (Table 2).

\section{Systematic}

Class Malacostraca Latreille, 1802.

Order Amphipoda Latreille, 1826.

Family Stenothoidae Boeck, 1871.

Subfamily Stenothoinae Boeck, 1871.

Genus Stenothoe Dana, 1852.

Stenothoe bosphorana Sowinsky, 1898.

Material examined: Three male specimens (cod. StB-1, StB-2, StB-3) collected in C area in 2018.

Diagnosis: The species presents a sexual dimorphism (Ruffo, 1993).

Table 1 Survey areas with geographical position, mean depth and bottom type

\begin{tabular}{|c|c|c|c|c|c|c|}
\hline Area & Vertex & Long & Lat & Mean Depth & Bottom Type & Location \\
\hline A & $\begin{array}{l}\text { a1 } \\
\text { a2 }\end{array}$ & $\begin{array}{l}44^{\circ} 04^{\prime} \\
12^{\prime \prime}, 84 \mathrm{~N} \\
44^{\circ} 02^{\prime} \\
28^{\prime \prime}, 38 \mathrm{~N}\end{array}$ & $\begin{array}{c}13^{\circ} 31^{\prime} \\
57^{\prime \prime}, 54 \mathrm{E} \\
13^{\circ} 34^{\prime} \\
32^{\prime \prime}, 34 \mathrm{E}\end{array}$ & $75 \mathrm{~m}$ & silty-sands & $\begin{array}{l}45 \mathrm{~km} \text { from the Italian coast } \\
\text { in front of Pesaro }\end{array}$ \\
\hline $\mathrm{B}$ & $\begin{array}{l}\mathrm{b} 1 \\
\mathrm{~b} 2\end{array}$ & $\begin{array}{l}43^{\circ} 48^{\prime} 53^{\prime \prime} \mathrm{N} \\
43^{\circ} 47^{\prime} 6^{\prime \prime} \mathrm{N}\end{array}$ & $\begin{array}{l}14^{\circ} 0^{\prime} 20^{\prime \prime} \mathrm{E} \\
14^{\circ} 2^{\prime} 51^{\prime \prime} \mathrm{E}\end{array}$ & $75 \mathrm{~m}$ & clay-silt & $\begin{array}{l}45 \mathrm{~km} \text { from the Italian coast } \\
\text { in front of Ancona }\end{array}$ \\
\hline $\mathrm{C}$ & $\begin{array}{l}\mathrm{c} 1 \\
\mathrm{c} 2\end{array}$ & $\begin{array}{l}43^{\circ} 36^{\prime} 47^{\prime} \mathrm{N} \\
43^{\circ} 34^{\prime} 56^{\prime \prime} \mathrm{N}\end{array}$ & $\begin{array}{l}14^{\circ} 19^{\prime} 03^{\prime \prime} \mathrm{E} \\
14^{\circ} 21^{\prime} 37^{\prime \prime} \mathrm{E}\end{array}$ & $80 \mathrm{~m}$ & silty-sand & $\begin{array}{l}60 \mathrm{~km} \text { offshore, further south-east } \\
\text { than area B }\end{array}$ \\
\hline
\end{tabular}


Table 2 Specimens of E. nana, L. affinis, L. siphonatus and S. bosphorana recorded from 2012 to 2018 surveys in the three areas

\begin{tabular}{llll}
\hline & Number of records & Area & Survey \\
\hline Eudorella nana & 6 & A & 2012 \\
Leucon affinis & 1 & B & 2017 \\
& 6 & A & 2012 \\
Leucon siphonatus & 1 & A & 2014 \\
& 1 & B & 2015 \\
& 2 & B & 2018 \\
& 1 & B & 2019 \\
& 16 & A & 2012 \\
& 7 & A & 2013 \\
& 6 & A & 2014 \\
& 16 & B & 2013 \\
& 42 & B & 2014 \\
& 31 & B & 2015 \\
& 70 & B & 2016 \\
& 64 & B & 2017 \\
& 13 & B & 2018 \\
& 3 & B & 2019 \\
& 2 & C & 2013 \\
& 1 & C & 2014 \\
& 1 & C & 2016 \\
& 3 & C & 2018 \\
& & & 2018 \\
\hline
\end{tabular}

According to Bellan-Santini et al. (1993) and KrappSchickel (2015).

TL: $3.5-4.1 \mathrm{~mm}$. Submarginal spines and marginal setae on the telson. Body smooth. Pereopods not prehensile. Eyes present. Antenna 1 and 2 long and slender. Gnatopod 1 feeble, propodus slender and oval, carpus free posterior margin parallel to the anterior one, palm undefined, merus a little shorter than carpus. Gnatopod 2 propodus strong, palm distally serrated with 5-6 protuberances (Fig. 2a). Pereopod 7 (P7) merus reaching distal end of carpus (Fig. 2b).

Ecology and distribution: $S$. bosphorana is known to live on muddy bottoms between 35 and $360 \mathrm{~m}$ (Bellan-Santini et al. 1993).

As above mentioned, S. bosphorana is still considered an endemic species in the Mediterranean Sea (KrappSchickel 2015), where it is distributed in the eastern part of the basin, from the Sea of Marmara and North Aegean Sea to the Levantine Sea (Krapp-Schickel 1976; Manoudis et al. 2005; Bakir et al. 2014). Fewer records were also registered in the western part of the Mediterranean, particularly in Saint-Tropez Gulf and alongside the Tunisian coast (Chevreux and Fage 1925; Zakhama-Sraieb et al. 2009).
Up to date, no further records are available in literature for this species, except for an uncertain one at the Azores which is still under debate (Krapp-Schickel 1976; Bellan-Santini 2005).

Order Cumacea Krøyer, 1846.

Family Leuconidae Sars, 1878.

Genus Eudorella Norman, 1867.

Eudorella nana Sars, 1879.

Material examined: Six female individuals (cod. EuN-1, EuN-2, EuN-3, EuN-4, EuN-5, EuN-6) collected in A area in 2012.

Diagnosis: According to Băcescu (1951), Fage (1951), Jones (1976) and Shalla (2011).

TL: $1.2-3.8 \mathrm{~mm}$. Carapace anteriorly truncate without prominent pseudorostrum (Fig. 3); efferent orifice dorsal. Anterior lateral part of carapace shaped in an evident, horizontal, elongated tip forming a unique tooth in the male and few much shorter teeth in the female; immediately above, a Vshaped excavation with a single upwards pointed tooth on top; an evident sheaf of long bristles on the posterior margin of the fifth abdominal segment.

Ecology and distribution: E. nana is considered typical of circalittoral habitats, living in different types of sediment, from sandy bottoms to coastal terrigenous mud, as well as in coastal detritic, muddy detritic, and shelf-edge detritic bottoms (Carpine 1970; Ledoyer 1983; Corbera and Cardell 1995). It is considered an endemic species recorded in the Western Mediterranean Sea (Fage 1940, 1951; Carpine 1970; Reyss 1972; Ledoyer 1983, 1987; Coll et al., 2010; Marusso 2010), in the Ionian Sea and in the Aegean Sea (Mühlenhardt-Siegel 2009; Reyss 1974).

Even though Watling (1991) questioned the validity of the species $E$. nana, he included it in the species list belonging to the genus, while Cartes and Sorbe (1997) did not separate the species E. nana and E. truncatula (Bate, 1856), considering both as E. truncatula. Several taxonomists still discriminate E. nana and E. trincatula as two different species (Fage, 1951; Carpine 1970; Reyss 1972; Ledoyer 1983; Corbera and Cardell 1995; Mühlenhardt-Siegel 2009; Coll et al., 2010; Marusso 2010; Koulouri et al. 2016; WoRMS Editorial Board 2020).

Genus Leucon Krøyer, 1846.

Subgenus Leucon Kroyer, 1846.

Leucon (Leucon) affinis Fage, 1951.

Material examined: Six females (cod. LeAff-1, LeAff-2, LeAff-3, LeAff-4, LeAff-5, LeAff-6) collected in A area in 2012.

Diagnosis: According to Băcescu (1951), Fage (1951), Jones (1976) and Shalla (2011).

TL: $1.8-3.6 \mathrm{~mm}$. Carapace $1 / 4$ of the total length; pseudorostrum straight largely cut off at the top; dorsal ridge with an anterior batch of 16 contiguous teeth, followed by a smooth and concave depression and by another series of 4 
Fig. 2 Stenothoe bosphorana Sowinsky, 1898. Male StB-1; a: Gn2, b: P7

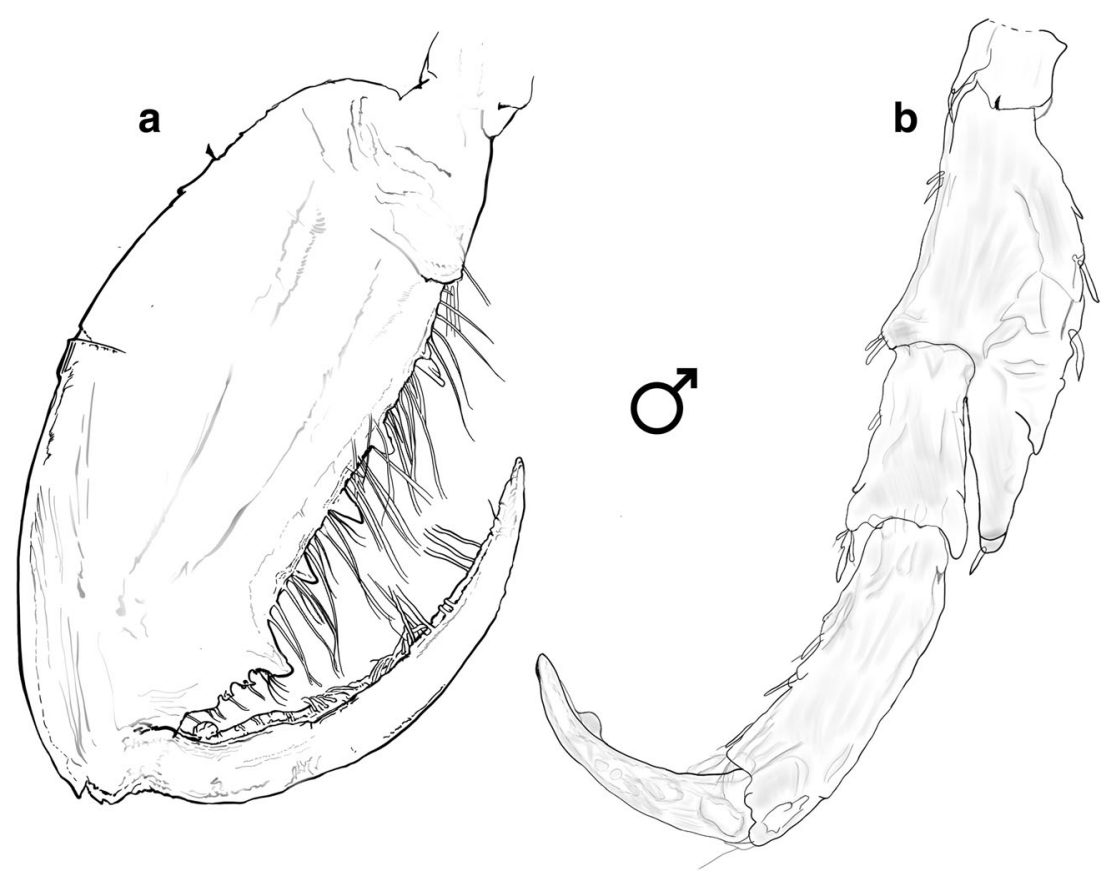

teeth extending up to the rear edge of the carapace; peduncle of uropods with the same length of endopod, which is a little shorter than exopod.

Ecology and distribution: L. affinis is a bathyal species, living from 180 to $415 \mathrm{~m}$ depth (Mühlenhardt-Siegel 2009) in sandy bottoms and in deep-sea muds (Carpine 1970; Ledoyer 1983,1987; Corbera and Cardell 1995).

Some authors recorded this species in northeast Atlantic Ocean (Corbera and Sorbe 2020), in Western Mediterranean (Fage 1951; Carpine 1970; Reyss 1972; Ledoyer 1983; Mühlenhardt-Siegel 2009; Coll et al., 2010) and in Ionian and Levantine seas (Mühlenhardt-Siegel 2009; Coll et al., 2010), specifying that it might be confused with L. fulvus Sars, 1865 and L. acutirostris Sars, 1865, which are common in the northern Atlantic Ocean (Fage 1951; Gerken and Watling 1999).

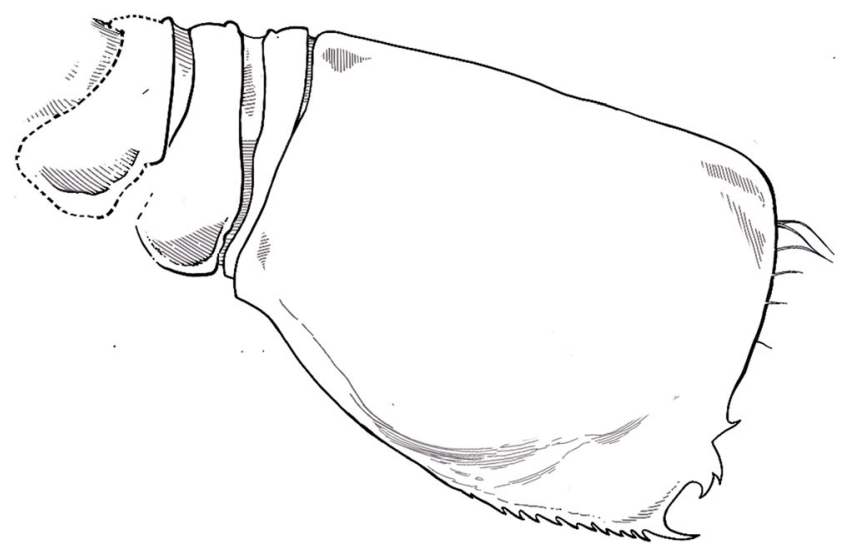

Fig. 3 Eudorella nana Sars, 1879, female EuN-1, carapace

\section{Subgenus Macrauloleucon Watling, 1991. Leucon (Macrauloleucon) siphonatus Calman, 1905.} Material examined:

Sixteen female specimens (cod. LeSip-1, LeSip-2, LeSip3, LeSip-4, LeSip-5, LeSip-6, LeSip-7, LeSip-8, LeSip-9, LeSip-10, LeSip-11, LeSip-12, LeSip-13, LeSip-14, LeSip15, LeSip-16) collected in A area in 2012.

Diagnosis: According to Băcescu (1951), Fage (1951), Jones (1976) and Shalla (2011).

TL: 1.7-3.1 mm. Elongated branchial siphon developing from the front of pseudorostrum, accompanied by long bristles; dorsal and antero-lateral edge of carapace with some teeth; distal end of endopod with a long apical plumose bristle and four internal spines, exopod with internal and external bristles on margins.

Distribution: L. siphonatus is reported as a bathyal species, typical of sandy bottoms and deep-sea muds (Carpine 1970; Ledoyer 1987, 1983; Corbera and Cardell 1995).

It was recorded in the Atlantic Ocean, in the west coast of Iceland, Ireland, in the Bay of Biscay (Hansen 1920; Fage 1929; Reyss 1972; Gerken and Watling 1999; Corbera and Sorbe 2020), and in different areas of the Mediterranean Sea: Western Mediterranean Sea (Calman 1906; Fage 1940; Reyss 1972; Ledoyer 1987, 1983), Tyrrhenian, Ionian and Levantine Seas (Klepal and Kastner 1980; Madurell and Cartes 2003; Mühlenhardt-Siegel 2009; Coll et al., 2010).

\section{Remarks}

The A area bottom, with an average depth of $75 \mathrm{~m}$, was characterized by sand (Shepard's classification). The 
Table 3 Total amphipod and cumacean taxa recorded from 2012 to 2018 surveys in the three areas

Taxa $\quad$ A

Order Amphipoda Latreille, 1802

Fam. Acidostomatidae Stoddart \& Lowry, 2012

Acidostoma obesum (Spence Bate, 1862)

B

$\mathbf{C}$

Total

Fam. Ampeliscidae Krøyer, 1842

Ampelisca diadema (Costa, 1853)

Ampelisca intermedia Bellan-Santini \& Diviacco, 1990

Ampelisca rubella A. Costa, 1864

Ampelisca rubella A. Costa, 1864

Amphilochoides sp.

Apolochus brunneus (Della Valle, 1893)

Apolochus neapolitanus (Della Valle, 1893)

Apolochus sp.

Fam. Ampithoidae Boeck, 1871

Ampithoe ramondi Audouin, 1826

Ampithoe sp.

4

Fam. Aoridae Stebbing, 1899

Aora gracilis (Spence Bate, 1857)

Aora sp.

Aora spinicornis Afonso, 1976

Fam. Aristiidae Lowry \& Stoddart, 1997

Perrierella audouiniana (Spence Bate, 1857)

Fam. Atylidae Lilljeborg, 1865

Nototropis guttatus Costa, 1853

Fam. Bathyporeiidae d'Udekem d'Acoz, 2011

Bathyporeia sp.

Fam. Calliopiidae G.O. Sars, 1893

Apherusa sp.

10

Fam. Caprellidae Leach, 1814

Caprella acanthifera Leach, 1814

Caprella rapax Mayer, 1890

Caprella sp.

Caprellidae ind.

Liropus elongatus Mayer, 1890

Pariambus typicus (Krøyer, 1845)

Phtisica marina Slabber, 1769

Pseudolirius kroyeri (Haller, 1879)

Pseudoprotella phasma (Montagu, 1804)

Fam. Cheirocratidae d'Udekem d'Acoz, 2010

Cheirocratus sundevallii (Rathke, 1843)

Fam. Colomastigidae Chevreux, 1899

Colomastix pusilla Grube, 1861

Fam. Corophiidae Leach, 1814

Corophium sp.

Leptocheirus guttatus (Grube, 1864)

Leptocheirus mariae Karaman, 1973

Leptocheirus sp.

Fam. Cyproideidae J.L. Barnard, 1974

Peltocoxa sp.

12

2

1

1

47

56

62

3

76

2
870

3

650

1

1

19

100

703

2

5

1

4

13

1

10

15

13

2

2

1

1

10

130

344

486

1

131

$8 \quad 361$

9

1

$$
1
$$

$$
1
$$

47

676

57

80

3

3

3

155

279

27

28

3

27

29

3

1 
Table 3 (continued)

Fam. Dexaminidae Leach, 1814

Dexamine spinosa (Montagu, 1813)

Fam. Eriopisidae Lowry \& Myers, 2013

Eriopisa elongata (Bruzelius, 1859)

Fam. Eusiridae Stebbing, 1888

Eusirus longipes Boeck, 1861

Fam. Iphimediidae Boeck, 1871 Iphimedia sp.

Fam. Ischyroceridae Stebbing, 1899

Ericthonius brasiliensis (Dana, 1853)

Ericthonius punctatus (Spence Bate, 1857)

Jassa marmorata Holmes, 1905

Fam. Leucothoidae Dana, 1852

Leucothoe incisa Robertson, 1892

Leucothoe lilljeborgi Boeck, 1861

Leucothoe oboa Karaman, 1971

Leucothoe pachycera Della Valle, 1893

Leucothoe sp.

Leucothoe spinicarpa (Abildgaard, 1789)

Fam. Liljeborgiidae Stebbing, 1899

Liljeborgia psaltrica Krapp-Schickel, 1975

Fam. Lysianassidae Dana, 1849

Lysianassa $\mathrm{sp.}$

Fam. Maeridae Krapp-Schickel, 2008

Elasmopus rapax Costa, 1853

Maera grossimana (Montagu, 1808)

Othomaera schmidtii (Stephensen, 1915)

Fam. Microprotopidae Myers \& Lowry, 2003

Microprotopus maculatus Norman, 1867

Fam. Oedicerotidae Lilljeborg, 1865

Kroyera carinata Spence Bate, 1857

Perioculodes aequimanus(Kossman, 1880)

Perioculodes longimanus (Spence Bate \& Westwood, 1868)

Westwoodilla rectirostris (Della Valle, 1893)

Fam. Pardaliscidae Boeck, 1871

Halice abyssi Boeck, 1871

Halicoides walkeri (Ledoyer, 1973)

Fam. Photidae Boeck, 1871

Gammaropsis sp.

Photis longicaudata (Spence Bate \& Westwood, 1862)

Fam. Phoxocephalidae G.O. Sars, 1891

Harpinia antennaria Meinert, 1890

Harpinia crenulata (Boeck, 1871)

Harpinia dellavallei Chevreux, 1910

Metaphoxus simplex (Spence Bate, 1857)

Paraphoxus oculatus (G. O. Sars, 1879)

$\begin{array}{ll} & 58 \\ & 24 \\ 178 & 667 \\ 12 & 1 \\ & 350\end{array}$

60

13

58

Fam. Podoprionidae Lowry \& Stoddart, 1996

Podoprion bolivari Chevreux, 1891

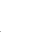

$$
\begin{aligned}
& 18 \\
& 45 \\
& 12 \\
& 1
\end{aligned}
$$$$
18
$$

85

86

33

1

8

2

5 
Table 3 (continued)

Fam. Stegocephalidae Dana, 1852

Stegocephaloides christianiensis Boeck, 1871

Fam. Stenothoidae Boeck, 1871

Stenothoe bosphorana Sowinsky, 1898

Stenothoe sp.

Stenothoe tergestina (Nebeski, 1881)

Fam. Tryphosidae Lowry \& Stoddart, 1997

Hippomedon bidentatus Chevreux, 1903

Hippomedon massiliensis Bellan-Santini, 1965

Hippomedon oculatus Chevreux \& Fage, 1925

Lepidepecreum longicornis (Spence Bate, 1862)

Orchomene grimaldii Chevreux, 1890

Fam. Uristidae Hurley, 1963

Ichnopus taurus Costa, 1853

Fam. Urothoidae Bousfield, 1978

Urothoe sp.

\begin{tabular}{|c|c|c|c|}
\hline & & 3 & 3 \\
\hline \multirow[t]{3}{*}{16} & 53 & 25 & 94 \\
\hline & 51 & 3 & 54 \\
\hline & 1 & & 1 \\
\hline \multirow[t]{2}{*}{21} & 2 & 2 & 25 \\
\hline & & 1 & 1 \\
\hline 10 & & & 10 \\
\hline \multirow[t]{2}{*}{257} & 154 & 199 & 610 \\
\hline & 6 & 10 & 16 \\
\hline 30 & 1 & & 31 \\
\hline 286 & 462 & 28 & 776 \\
\hline 72 & 4 & 1 & 77 \\
\hline 89 & 10 & & 99 \\
\hline 12 & & & 12 \\
\hline
\end{tabular}

Order Cumacea Krøyer, 1846

Cumacea ind

Fam. Bodotriidae T. Scott, 1901

Bodotria scorpioides (Montagu, 1804)

Iphinoe serrata Norman, 1867

Iphinoe sp.

Diastylis doryphora Fage, 1940

Diastylis rugosa Sars, 1865

Diastylis sp.

Ekleptostylis walkeri (Calman, 1907)

Makrokylindrus sp.

Fam. Leuconidae Sars, 1878

Eudorella nana Sars, 1879

Eudorella truncatula (Bate, 1856)

Leucon (Leucon) affinis Fage, 1951

Leucon (Leucon) mediterraneus Sars, 1878

Leucon (Macrauloleucon) siphonatus Calman, 1905

Fam. Nannastacidae Bate, 1866

Campylaspis nitens Bonnier, 1896

Campylaspis sp.

30

Nannastacus sp.

60

$\begin{array}{llll}6 & 1 & & 7 \\ 948 & 1057 & 60 & 2065 \\ 7 & 4 & & 11 \\ 75 & 60 & 1 & 136 \\ 25 & 242 & 7 & 274 \\ & & & \\ & 3 & & 3 \\ 30 & 14 & 1 & 45 \\ 60 & & & 60\end{array}$

macrozoobenthos community herein was dominated by the following taxa: Ditrupa arietina (O. F. Müller, 1776), Sabellidae nd. Latreille, 1825, Prionospio cirrifera Wirén, 1883, Paraonidae nd. Cerruti, 1909 and Aphelochaeta filiformis (Keferstein, 1862). Area B, $75 \mathrm{~m}$ mean depth, was characterized by a silty-sand bottom and the dominant macrozoobenthos taxa were Paraonidae nd., Ophelina cylindricaudata (Hansen,
1879), Paradiopatra calliopae Arvantidis \& Koukouras, 1997, Aphelochaeta filiformis and Prionospio cirrifera. The sea bottom of $\mathrm{C}$ area was mainly silty-sand with an average depth of $80 \mathrm{~m}$. The most abundant taxa in the macrozoobenthos community herein were Paraonidae nd., Ophelina cylindricaudata, Prionospio cirrifera, Paradiopatra calliopae, Callianassa subterranea (Montagu, 1808) and Aphelochaeta filiformis. 
Considering the amphipods and cumaceans associated with the species recorded in this paper, in the three areas A, B and C a total of 57,71 and 60 taxa were respectively found (Table 3). E. truncatula was the most abundant species in both areas A and B. Ampelisca diadema (Costa, 1853) was one of the dominant species in all the considered areas, together with Phtisica marina Slabber, 1769 (A area), Harpinia dellavallei Chevreux, 1910 (B area), Paraphoxus oculatus (G. O. Sars, 1879) and Orchomene grimaldii Chevreux, 1890 (C area).

\section{Discussion}

The taxonomic misidentification issue plays an important role in the marine biodiversity management, especially for very small-sized marine species. Furthermore, genetic analysis on these specimens is problematic as the small and fragile body makes difficult to collect suitable samples.

This study is aimed to contribute to the knowledge on the families Leuconidae and Stenothoidae distribution. In fact, several authors, as well as both European Register of Marine Species (Costello et al. 2020) and World Register of Marine Species (WoRMS Editorial Board 2020), report the distribution of the four species here recorded in different areas of the Mediterranean Sea (Watling 2001; Coll et al. 2010; Watling and Gerken 2014; WoRMS Editorial Board, 2020) without any (or only one old record in the case of $S$. bosphorana) information on their presence in the Adriatic Sea; moreover the "Italian Checklist of Marine Fauna" (Marusso 2010) does not report E. nana and L. siphonatus in the Adriatic section, and $L$. affinis and $S$. bosphorana in all Italian seas.

Only 3 specimens of $S$. bosphorana were found in siltysand bottom at $80 \mathrm{~m}$ depth in Adriatic Sea during the overall sampling period (from 2012 to 2019), highlighting the rareness of this species in this basin. Since this taxon was previously only reported living on muddy bottoms, this record adds a different bottom type where it can be found, also widening the living area.

The E. nana living habit fit with the environmental characteristics of the A and B areas where it was found, considered typical of the circalittoral zone and living in a wide range of bottom type, this record adds the Adriatic Sea to the E. nana living area, giving new information on its distribution.

In this study, L. affinis and L. siphonatus, until now considered as bathyal species living mainly on sandy and muddy deep-sea bottom, were found in shallow waters living in sand and silty-sand bottom of the Adriatic Sea, between 75 and $80 \mathrm{~m}$ depth, thus providing further information on their habitat and distribution.

The new record of the four species in the Adriatic Sea could be explained by the hypothesis that these species were already present in Adriatic, although not common, but had not yet been identified due to the poor knowledge about these taxa and the limited number of studies on these orders of crustacea, their small size and fragility and the difficulties to collect undamaged specimens using the common sampling techniques.

Further specific studies would be essential to better know the distribution of these taxa in this basin and therefore understand their ecological role in the benthic community.

Availability of Data and Material Voucher specimens are presently kept in the reference collection of CNR-IRBIM in Ancona, Italy. No other data sets are generated during this study.

Code Availability Not applicable.

Authors' Contributions Pierluigi Strafella main author, draft the work, participated to sampling survey, analyzed the samples and validated the taxonomic records; Vera Salvalaggio analyzed the samples, cooperated in the paper writing and the taxonomic validation, managed the sampling survey; Clara Cuicchi supported the paper writing and the taxonomic validation; Elisa Punzo contributed in the paper writing and the taxonomic validation; Angela Santelli analyzed the samples, supported the paper writing and the taxonomic validation; Alessandro Colombelli supported the paper writing, drew the images; Gianna Fabi coordinator of the research, organized and led the scientific cruise, approved the version to be published; Alessandra Spagnolo responsible of the research, contributed in the paper writing and approved the version to be published.

Funding This study received funding from ENI S.p.A.-UPSTREAM DICS.

\section{Declarations}

Conflicts of Interest/Competing Interests The authors declare that they have no conflict of interest or competing financial and/or non-financial interests in relation to this work.

Ethics Approval This article does not contain any studies with animals performed by any of the authors.

Consent to Participate Sampling and observational field studies do not require any permits.

\section{Consent for Publication Not applicable.}

Open Access This article is licensed under a Creative Commons Attribution 4.0 International License, which permits use, sharing, adaptation, distribution and reproduction in any medium or format, as long as you give appropriate credit to the original author(s) and the source, provide a link to the Creative Commons licence, and indicate if changes were made. The images or other third party material in this article are included in the article's Creative Commons licence, unless indicated otherwise in a credit line to the material. If material is not included in the article's Creative Commons licence and your intended use is not permitted by statutory regulation or exceeds the permitted use, you will need to obtain permission directly from the copyright holder. To view a copy of this licence, visit http://creativecommons.org/licenses/by/4.0/. 


\section{References}

Artegiani A, Paschini E, Russo A, Bregant D, Raicich F, Pinardi N (1997) The Adriatic Sea general circulation. Part I: Air-Sea interactions and water mass structure. J Phys Oceanogr 27(8):1492-1514. https:// doi.org/10.1175/1520-0485(1997)027<1492:TASGCP >2.0.CO;2

Băcescu M (1951) Fauna Republicii Populare Române IV Crustacea I Cumacea Acad Republicii Pop Române 1, 93

Bakir AK, Katağan T, Aker HV, Özcan T, Sezgin M, Ateş AS, Koçak C, Kirkim F (2014) The marine arthropods of Turkey. Turkish J Zool 38(6):765-831. https://doi.org/10.3906/zoo-1405-48

Bellan-Santini D (2005) Stenothoidae (Crustacea: Amphipoda) of hydrothermal vents and surroundings on the mid-Atlantic ridge, Azores triple junction zone. J Nat Hist 39(39):3435-3452. https://doi.org/ $10.1080 / 00222930500345749$

Bellan-Santini D, Karaman G, Krapp-Schickel T, Ledoyer M, Ruffo S (1993) The Amphipoda of the Mediterranean. Part 3: Gammaridea (Melphidippidae to Talitridae), Ingolfiellidea, Caprellidea., in: Ruffo, Sandro (Ed.), the Amphipoda of the Mediterranean. Part 3, memoires de l'Institut Oceanographique. Monaco, pp. 577-813

Boeck A (1871) Crustacea Amphipoda borealia et arctica. Forh Vidensksabsselskabet i Kristiania 83-279

Bousfield EL (1982) Amphipoda. In: Parker SP (ed) Synopsis and classification of living organisms. McGrawHill, New York, pp 241-293

Calman WT (1906) The Cumacea of the puritan expedition. Mitth. Aus der Zool. Stn. Zu Neapal 17:411-432, pls. 27, 28

Carpine C (1970) Écologie de l'étage bathyal dans la Méditerranée occidentale. Mémoires de l'Institut Océanographique, Monaco 2: $1-146$

Cartes JE, Mamouridis V, Fanelli E (2011) Deep-sea suprabenthos assemblages (Crustacea) off the Balearic Islands (western Mediterranean): Mesoscale variability in diversity and production. J Sea Res 65:340-354

Cartes JE, Papiol V, Palanques A, Guillén J, Demestre M (2007) Dynamics of suprabenthos off Ebro Delta (Catalan Sea: western Mediterranean): spatial and temporal patterns and relationships with environmental factors. Estuar Coast Shelf Sci 75:501-515

Cartes JE, Sorbe JC (1997) Bathyal Cumaceans of the Catalan Sea (North-Western Mediterranean): faunistic composition, diversity and nearbottom distribution along the slope (between 389 and 1859 m). J Nat Hist 31:1041-1054

Casellato S, Masiero L, Sichirollo E, Soresi S (2007) Hidden secrets of the northern Adriatic: "Tegnue", peculiar reefs. Cent Eur J Biol 2: $122-136$

Casellato S, Stefanon A (2008) Coralligenous habitat in the northern Adriatic Sea: an overview. Mar Ecol 29:321-341

Chevreux E, Fage L (1925) Amphipodes. Faune de France, 9. P. Lechevalier, Paris, 488 pp.

Coll M, Santojanni A, Palomera I, Tudela S, Arneri E (2007) An ecological model of the northern and Central Adriatic Sea: analysis of ecosystem structure and fishing impacts. J Mar Syst 67(1-2):119154. https://doi.org/10.1016/j.jmarsys.2006.10.002

Coll M, Piroddi C, Steenbeek J, Kaschner K, Ben Rais Lasram F, Aguzzi J, Ballesteros E, Bianchi CN, Corbera J, Dailianis T, Danovaro R, Estrada M, Froglia C, Galil BS, Gasol JM, Gertwagen R, Gil J, Guilhaumon F, Kesner-Reyes K, Kitsos MS, Koukouras A, Lampadariou N, Laxamana E, López-Fé de la Cuadra CM, Lotze HK, Martin D, Mouillot D, Oro D, Raicevich S, Rius-Barile J, SaizSalinas JI, San Vicente C, Somot S, Templado J, Turon X, Vafidis D, Villanueva R, Voultsiadou E (2010) The biodiversity of the Mediterranean Sea: estimates, patterns, and threats. PLoS One 5(8):e11842. https://doi.org/10.1371/journal.pone.0011842

Corbera J, Cardell MJ (1995) Cumaceans as indicators of eutrophication of soft bottoms. Sci Mar 59:63-69
Corbera J, Sorbe JC (2020) Bathyal cumacean assemblages from the southern margin of the cap ferret canyon (SE Bay of Biscay). Sci Mar 84(2). https://doi.org/10.3989/scimar.05031.07A

Costello, M.J.; Bouchet, P.; Boxshall, G.; Arvanitidis, C.; Appeltans, W. (2020). European register of marine species. Accessed at http:// www.marbef.org/data/erms.php on 2020-10-26

Directive 2008/56/EC of the European Parliament and of the Council of 17 June 2008 establishing a framework for community action in the field of marine environmental policy (Marine Strategy Framework Directive)

Dubois AD, Crochet PC, Dickinson ECD, Nemésio AN, Aescht EA, Aaron M, Bauer B, Blagoderov VB, Bour RB, Carvalho MRDEC, Desutter-Grandcolas LD, Frétey TF, Jager PJ, Koyamba VK, Lavilla EOL, Lobl I, Louchart L, Malécot V, Schatz H, Ohler A (2013) Nomenclatural and taxonomic problems related to the electronic publication of new nomina and nomenclatural acts in zoology, with brief comments on optical discs and on the situation in botany. Zootaxa 3735(1):1-94. https://doi.org/10.11646/zootaxa.3735.1.1

Elizalde M, Sorbe J, Dauvin J (1993) Las comunidades suprabentonicas batiales del golfo de Vizcaya (margen sur del canon de Cap-Ferret): composicion faunõstica y estructura. Publ Espec Inst Esp Ocean 11: 247-258

Fabi G, Manoukian S, Spagnolo A (2009) Impact of an open-sea suspended mussel culture on macrobenthic community (Western Adriatic Sea). Aquaculture 289(1-2):54-63. https://doi.org/10. 1016/j.aquaculture.2008.12.026

Fage L (1929) Cumacés et Leptostracés provenant des campagnes scientifiques de S.A.S. le Prince Albert de Monaco. Résultats des Campagnes Sci. Accompl. sur son Yacht par Albert 1er Prince Souver. Monaco 77:1-51

Fage L (1940) Les Cumacés de la Mediterranée, remarques systematiques et biologiques. Bull l'Institut Océanographique 783:1-14

Fage L (1951) Cumacés. Faune the France 54. P. Lechevalier, Paris, 136 pp.

Fanelli E, Cartes JE, Badalamenti F, Rumolo P, Sprovieri M (2009) Trophodynamics of suprabenthic fauna on coastal muddy bottoms of the southern Tyrrhenian Sea (western Mediterranean). J Sea Res $61: 174-187$

Frutos I, Sorbe JC (2017) Suprabenthic assemblages from the Capbreton area (SE Bay of Biscay). Faunal recovery after a canyon turbidity disturbance. Deep-Sea Research Part I Oceanographic Research Papers 130:36-46. https://doi.org/10.1016/j.dsr.2017.10.007

Frutos I, Sorbe JC (2014) Bathyal suprabenthic assemblages from the southern margin of the Capbreton canyon ("Kostarrenkala" area), SE Bay of Biscay. Deep-Sea Res II Top Stud Oceanogr 104:291309. https://doi.org/10.1016/j.dsr2.2013.09.010

Gerken S, Watling L (1999) Cumacea (Crustacea) of the Faroe Island region. Frodskaparrit 47:199-227

Graeffe E (1902) Uebersicht der Fauna des Golfes von Triest nebst Notizen über Vorkommen, Lebensweise, Erscheinungs-und Laichzeit der einzelnen Arten, in: Hölder, A. (Ed.), Arbeiten Aus Den Zoologischen Instituten Der Universität Wien Und Der Zoologischen Station in Triest. Wien, pp. 33-80

Hansen HJ (1920) Crustacea Malacostraca IV. Danish Ingolf Exped 3:186

Hayward BW, Morley MS (2005) Zonation and biogeography of the intertidal biota of Subantarctic Campbell and Auckland Islands, New Zealand Rec Auckl Inst Museum 7-33

Jones NS (1976) British Cumaceans. Synopses of the British Fauna, 7. London

Klepal W, Kastner RT (1980) Morphology and differentiation of nonsensory cuticular structures in Mysidacea, Cumacea and Tanaidacea (Crustacea, Peracarida). Zool Scr 9:271-281

Koulouri P, Gerovasileiou V, Bailly N (2016) Cumacea of Greece: a preliminary checklist. Biodivers Data J 4:e9287. https://doi.org/10. 3897/BDJ.4.e9287 
Krapp-Schickel T (1976) Die gattung Stenothoe (Crustacea, Amphipoda) im Mittelmeer. Budragen Tot Dierkd 46:1-34

Krapp-Schickel T (2006) New Australian Stenothoids (Crustacea, Amphipoda) with key to all Stenothoe species. Boll del Mus Civ di Stor Nat di Verona 30:39-56

Krapp-Schickel T (2015) Minute but constant morphological differences within members of Stenothoidae: the Stenothoe gallensis group with four new members, keys to Stenothoe worldwide, a new species of Parametopa and Sudanea n. gen. (Crustacea: Amphipoda). J Nat Hist 49(37-38):2309-2377. https://doi.org/10.1080/00222933. 2015.1021873

Krapp-Schickel T, Häussermann V, Vader W (2015) A new Stenothoe species (Crustacea: Amphipoda: Stenothoidae) living on Boloceropsis platei (Anthozoa: Actiniaria) from Chilean Patagonia. Helgol Mar Res 69(2):213-220. https://doi.org/10. 1007/s10152-015-0430-y

Krapp-Schickel T, Koenemann S (2006) Cladistic analysis of the family Stenothoidae. Contrib to Zool 75:169-188

Krapp-Schickel T, Lo Brutto S (2015) Two new Mediterranean Stenothoe (Crustacea, Amphipoda) from the coast of Israel. Mar Biodivers Rec 8. https://doi.org/10.1017/S1755267215000639

Lagardère JP (1977) Recherches sur la distribution verticale et sur l'alimentation des crustacés decapodes benthiques de la pente continentale du Golfe de Gascogne. Bull Cent Etud Rech Scient Biarritz 11:367-440

Ledoyer M (1987) Les Cumacés Mediterranéens profonds (Crustacea) des campagnes Biomedes I et II et Balgim. Synthese de la distribution bathyale du groupe en Mediterranée occidentale Mesogée 47: $59-70$

Ledoyer M (1983) Contribution à l'étude de l'écologie de la faune vagile profonde de la Méditerranée nord-occidentale 2. Les Cumacés (Crustacea). Téthys 11:67-81

Ligas A, De Biasi AM, Demestre MLP, Sartor P, Cartes JE (2009) Effects of chronic trawling disturbance on the secondary production of suprabenthic and infaunal crustacean communities in the Adriatic Sea (NW Mediterraean). Ciencias Mar 35:195-207

Madurell T, Cartes JE (2003) The suprabenthic peracarid fauna collected at bathyal depths in the Ionian Sea (eastern Mediterranean). Crustaceana 76:611-624

Manoudis G, Antoniadou C, Dounas K, Chintiroglou C (2005) Successional stages of experimental artificial reefs deployed in Vistonikos gulf North successional stages of experimental artificial reefs deployed in Vistonikos gulf(Aegean Sea, Greece): preliminary results. Belgian J Zool 135(2):209-215

Marin I, Sinelnikov S (2018) Two new species of amphipod genus Stenothoe Dana, 1852 (Stenothoidae) associated with fouling assemblages from Nhatrang Bay, Vietnam. Zootaxa 4410(1):057076. https://doi.org/10.11646/zootaxa.4410.1.3

Marusso V (2010) Checklist della Flora e della Fauna dei Mari Italiani (Parte II). Cumacea (Crustacea: Malacostraca). Biol Mar Mediterr $17: 484-486$

Mühlenhardt-Siegel U (2009) Cumacea (Crustacea, Peracarida) in the deep Mediterranean, with the description of one new species. Zootaxa 2096:413-432
Myers AA (1985) Shallow-water, coral reef and mangrove Amphipoda (Gammaridea) of Fiji, Records of the Australian Museum. Supplement. 5:1-143. https://doi.org/10.3853/j.0812-7387.5.1985. 99

Ponti M, Colangelo AM, Ceccherelli UV (2007) Composition, biomass and secondary production of the macrobenthic invertebrate assemblages in a coastal lagoon exploited for extensive aquaculture: Valle Smarlacca (northern Adriatic Sea). Estuar Coast Shelf Sci 75(1-2): 79-89. https://doi.org/10.1016/j.ecss.2007.01.021

Pranovi F, Anelli Monti M, Caccin A, Colla S, Zucchetta M (2016) Recreational fishing on the west coast of the northern Adriatic Sea (Western Mediterranean) and its possible ecological implications. Reg Stud Mar Sci 3:273-278. https://doi.org/10.1016/j.rsma.2015. 11.013

Reyss D (1972) Résultats scientifiques de la campagne du N.O. "Jean Charcot” en Méditerranée occidentale, mai-juin-juillet 1970 Cumacés. Crustaceana 3:362-377

Reyss D (1974) Cumacés Résultats scientifiques de la campagne "polymède II" du N.o. "Jean Charcot" en Mer Ionienne et en Mer Égée (Avril-Mai 1972). Crustaceana 27(2):216-222

Ruffo S (1993) The Amphipoda of the Mediterranean, part 3 Gammaridea (Melphidippidae to Talitridae); Ingolfiellidea; Caprellidea. Ed. Memoires de l'Institut Oceanographique Fondation Albert I Prince de Monaco. 252 pp. ISSN 0304-5714

Sars GO (1892) Amphipoda, in: account of the Crustacea of Norway; Vol. 1. Bergen museum, Christiania; Copenhagen, p. 711

Shalla SH (2011) Cumacea - identification guide to the British cumaceans, in: NMBAQC 2010 taxonomic workshop. Dove Marine Laboratory, Newcastle, pp. 1-46

Vader W (1984) Associations between amphipods (Crustacea: Amphipoda) and sea anemones (Anthozoa: Actiniaria). Aust Museum Mem 18:141-153

Vader W, Krapp-Schickel T (1996) Redescription and biology of Stenothoe brevicornis Sars (Amphipoda: Crustacea), an obligate associate of the sea anemone Actinostola callosa (Verrill). J Nat Hist 30(1):51-66. https://doi.org/10.1080/00222939600770041

Watling L (2001) Cumacea, in: Costello M.J. et al. (Ed.), European register of marine species: a check-list of the marine species in Europe and a bibliography of guides to their identification. Collection Patrimoines Naturels, pp. 308-310

Watling L (1991) Revision of the Cumacean family Leuconidae. J Crustac Biol 11:569-582

Watling L, Gerken S (2014) World Cumacea database [WWW Document]. http://www.marinespecies.org

Zakhama-Sraieb R, Sghaier YR, Charfi-Cheikhrouha F (2009) Amphipod biodiversity of the Tunisian coasts: update and distributional ecology. Mar Biodivers Rec 2(1). https://doi.org/10.1017/ S1755267209990820

WoRMS Editorial Board (2020) World Register of Marine Species. Available from http://www.marinespecies.org at VLIZ. Accessed 2020-10-26. doi:https://doi.org/10.14284/170

Publisher's Note Springer Nature remains neutral with regard to jurisdictional claims in published maps and institutional affiliations. 